\title{
The League of Nations and the Power of "Experiment Narratives" in International Institutional Law
}

\author{
Jean d'Aspremont \\ Professor of International Law, Sciences Po Law School, Paris, France \\ Chair of Public International Law, University of Manchester, Manchester, UK \\ jean.daspremont@sciencespo.fr
}

\begin{abstract}
This article engages with the image of the League of Nations as an experiment in international law and the law of international institutions. This image populates international legal literature of the second half of the 2oth century and of the 21st century. It corresponds to what is called here the "experiment narrative" about the League. Many of the claims made about international institutional law, collective security and international institutions in international legal discourses are informed by this specific narrative. Drawing on the "experiment narratives" about the League, this article shows that "experiment narratives" in international law constitute a common tool for international lawyers to uphold a progressive and linear global history and to organize their discourses.
\end{abstract}

\section{Keywords}

international law - the history of international law - critical history - the League of Nations - collective security - international organizations

\section{Introduction}

The League of Nations occupies a very particular place in the consciousness as well as imaginary of international lawyers. Scholarly studies on the League of Nations, its architecture, its practice, its flaws and limitations, and its 
achievements continue to abound in the 21st century. ${ }^{1}$ Unsurprisingly, this unabating interest for the League and the flourishing literature produced on the subject carry a wide range of distinct images of the League. For instance, the League is commonly represented as the receptacle of a utopia, a missed opportunity, a noble rupture from a dark age, a long awaited institutionalization of the international society, the start of an epoch, the germ of a new international law, a naïve institutional trial, a predictable fiasco, a victim of power politics, and so forth. These images of the League and their corresponding narratives are not only of an extreme diversity - often contradicting one another - but have also greatly varied and fluctuated over time. It suffices to recall how the hopeful narratives about the League that prevailed in international law circles in the 1920 s were supplanted by narratives informed by disheartenment in the 1930 and narratives of failures in the wake of the second World War.

This contribution zeroes in on a specific image of the League, namely the image of the League of Nations as an experiment in international law and the law of international institutions. This image corresponds to what is called here the "experiment narrative" about the League. This article's focus on "experiment narratives" about the League is premised on the centrality of such narrative in the international legal literature of the second half of the 2oth century and of the 21st century. In fact, as will be shown in the following paragraphs, many of the claims made about international institutional law, collective security and international institutions in international legal discourses are informed by this specific narrative. This article's engagement with "experiment narratives" about the League will enable a more important claim about the international legal discourses themselves. Drawing on the "experiment narratives" about the League, this article will show that "experiment narratives" in international law constitute a convenient tool for international lawyers to uphold a progressive and linear global history and to organize their discourses on international institutional law, collective security, and international institutions.

This discussion of international lawyers' "experiment narratives" about the League of Nations proceeds as follows. The first section elaborates on the notion of "experiment narratives" as it is construed here (section 2). The second section sketches out the diversity of narratives witnessed in international legal scholarship about the League (section 3). The third section expounds on the

1 For a few recent examples, see Patrick Cottrell, The League of Nations: Enduring Legacies of the First Experiment at World Organization (2018); Jackson, Simon, and Alanna O'Malley (eds.), The Institution of International Order: From the League of Nations to the United Nations (2018); Sunita Jogarajan, Double Taxation and the League of Nations (2018); Robert Kolb (ed.), Commentaire sur le Pacte de la Société des Nations (2015); Susan Pedersen, The Guardians: The League of Nations and the Crisis of Empire (2015). 
ways in which the League has come to be represented as an experiment and how the three abovementioned constitutive elements of "experiment narratives" concretely manifest themselves (section 4). This contribution ends with a few observations on what "experiment narratives" about the League of Nations tells us about how international lawyers build their discourses (section 5 ).

For the sake of this contribution, an "experiment narrative" refers to a narrative that represents a past practice or institution as having constituted an experiment. "Experiment narratives" are thus not themselves experimental, but they project an image of a past practice or institution as being experimental. Three features of "experiment narratives", as they are understood here, must be highlighted here.

First, "experiment narratives" come with a certain historicization by virtue of which the practice or institution concerned is located in a limited and well-delineated the past. In fact, for such practice or institution to constitute an experiment, it must be exclusively located in the past (and must no longer be continued in the present), thereby requiring that such past be formally captured through a beginning and an end. ${ }^{2}$ Short of having a clearly defined beginning and end, such practice or institution cannot be the object of an experiment narrative. In that sense, the first element of "experiment narratives" reduces such past practice or institution to an episode, ${ }^{3}$ this episode coming to an end and enabling a periodization in international legal discourses. ${ }^{4}$

2 Edward Said, Orientalism (1978) p. 24.

3 On the tendency to exaggerate change, see Hans-Georg Gadamer, Truth and Method (2013) p. xxiii.

4 On periodization and international law, see Oliver Diggelman, "The Periodization of the History of International Law" in B. Fassbender and A. Peters (eds.), The Oxford Handbook of the History of International Law (2012) pp. 996, 1003. See also the definition of William E. Butler, "Periodization and international law", in A. Orakhelashvili (ed.), Research Handbook on the Theory and History of International Law (2011) p. 379. Among general works on periodization, see Reinhart Koselleck, The Practice of Conceptual History (2002); Lawrence L. Besserman, The Challenge of Periodization: Old Paradigms and New Perspectives (1996); Marshall Brown, "Periods and Resistance", 62(4) Modern Language Quarterly (2001) p. 309; Jerry H. Bentley, "Cross-Cultural Interaction and Periodization in World History" 101(3) American Historical Review (1996) p. 749; William A. Green, "Periodizing World History", 34(2) History and Theory (1995) p. 99; Peter Stearns, "Periodization in World History Teaching", 20(4) History Teacher (1987) p. 561. For a powerful critique of Koselleck's model of periodization, see Kathleen 
Second, "experiment narratives" postulate that the past practice or institution concerned has not been successful all the way. On the contrary, "experiment narratives" presuppose a failure of the past practice or institution held as experimental, such failure being instrumental in its demise or discontinuation. This means that the second element thus projects a causality between a failure or demise and the discontinuity entailed by the first element. ${ }^{5}$ This second element also entails that "experiment narratives", as they are understood here, go hand-in-hand with a failure narrative.

Third, "experiment narratives", as they are envisaged here, postulate that the past practice or institution concerned has itself constituted a formative experience in the present. In that sense, "experiment narratives" postulate that current practices and institutions are informed by a form of knowledge or understanding generated by the past practice and institution held as being experimental. In that sense, "experiment narratives" presupposes a continuity between the past practice or institution and the present which is held as having benefited from the lessons of the said experiment. This third element thus re-establishes a continuity between the well-defined past and the present. It is this very continuity that allows those invoking "experiment narratives" to mobilize the past to create authority in the present. Location in a formally defined past (episode), narrativization of a failure or demise (causality), and attribution of formative merit in the present (continuity with the present) are the three intertwined constitutive elements of "experiment narratives" as they are understood here. ${ }^{6}$ It is the purpose of the following sections to show that how these three elements play out in international lawyers' narratives about the League of Nations.

\section{3} The Variety of Narratives about the League of Nations

There can be many different ways in which the past can be narrated. ${ }^{7}$ There are many possible past events, texts, scholarly works, figures that can be

Davis, Periodization and Sovereignty: How Ideas of Feudalism and Secularization Govern the Politics of Time (2008).

5 For a criticism of the obscurity of contemporary causal discourses, see Michel Foucault, L'achéologie du savoir (1969) p. 34.

6 It has been argued that this combination of continuity and discontinuity in discourses is a very modern characteristic. See Bruno Latour, Nous n'avons jamais été modernes. Essai d'anthropologie symétrique (1997), p. 20.

7 It is one of the greatest merits of Hayden Wide to have offered us a taxonomy of the emplotments techniques of 19th century historians. He distinguishes four modes of articulation by 
elevated into markers of a historical narrative. Likewise, there are multiple ways in which these events, texts, scholarly works, figures are causally arranged and periodized in order to generate what Bartes called the effet du réel ${ }^{8}$ (reality effect ${ }^{9}$ ). In other words, although, some historical narratives secure dominance and greater social acceptance at certain times and in certain places, ${ }^{10}$ international lawyers can choose from a wide range of possible historical narratives. ${ }^{11}$

The same holds with the League of Nations. ${ }^{2}$ There are many ways in which meaning can be given to the League of Nations, either as a practice or an institution with a view to creating an effet du réél in present international legal discourses. This is well illustrated in the international legal literature where the League of Nations is subject to many different narratives, themselves in constant fluctuation. ${ }^{13}$ It is true that, for most international lawyers, whether in 1920 s or today, the League constitutes the milestone of a major rupture. ${ }^{14}$ The way in which the League has brought about a breakaway from the past is however construed in a many different manners. ${ }^{15}$ For instance, for many, the League is construed as the first move away from the normality of war through

which the historian can gain explanatory effect of a specific kind as well as 4 emplotment. See Hayden White, Metahistory. The Historical Imagination in the 19th-CenturyEurope (2014) pp. 1-41. For a discussion of various ways to treat and organize historical materials see also Keith Jenkins, On 'What is History': From Carr and Elton to Rorty and White (1995) pp. 25-28. Roland Barthes, "le discours de l'histoire", 6(4) Social Science Information (1967) pp. 63, 74.

9 This is how Alun Munslow translated effet réel of Bartes (xiv), see Alun Munslow, "Preface" in Jenkins, supra note 7 , p. xiv.

10 White, supra note 7, p. 79. For a rejection of relativism and the idea that any interpretation is good as another, see Edward H.H. Carr, What is History? (2nd ed., 1987) p. 27.

11 In the same sense, Matthew Craven, "Introduction: International Law and Its Histories" in M. Craven, M. Fitzmaurice and M. Vogiatzi (eds.), Time, History and International Law (2007) p. 3 .

12 On the different ways to narrate the stories of international organizations, see Bhupinder S. Chimni, “International Organizations, 1945-Present", in J. Cogan, I. Hurd, and I.Johnstone (eds.), Oxford Handbook of International Organizations (2016) p. 113.

13 On the contrasts between the early literature on the League of nations and the postSecond World War literature, see Madeleine Herren, "International Organizations, 18651945", in Cogan, Hurd and Johnstone (eds.), ibid. p. 91.

14 Walter Schucking, Le développement du Pacte de la Société des Nations, Recueil des Cours (1927) p. 353; William Rappard, "Vues Rétrospectives sur la Société des Nations", ${ }_{71}$ Recueil des Cours (1947) p. 117, at 121, 174; Ronald Roxburgh, Oppenheim's International Law (3rd ed., 1920) pp. 300-301. David Kennedy however argues that League less a break than a continuation of the earlier violence and chaos. See David Kennedy, "The Move to Institutions" 8 Cardozo Law Review (1987) pp. 841, 867.

15 On the fact that League has been elevated as a break in multiple ways, see Kennedy, ibid. pp. 844-849. 
the collectivization of security. ${ }^{16}$ It is also represented as the first significant institutionalization of the "international society" as a whole ${ }^{17}$ or an actual step towards the universality thereof. ${ }^{18}$ Equally common is the image of the League as giving life to an utopia, as that envisaged by Kant, Rousseau or Abbé de Saint Pierre. ${ }^{19}$ Interestingly, a few others narratives about the League comes to flatly contradict the narratives that have just been mentioned. ${ }^{20}$ For instance, the narrative about the League as a legalizing moment and a move to law is countered by a representation of the League as a continuation of power politics in a more orderly manner. ${ }^{21}$

Irrespective of these varying - and sometimes contradictory - narratives about the League and the very distinct images they carry, there is one specific narrative that proves recurring and more or less constant: the representation of the League as an experiment. However one understands the rupture brought about by the League, most accounts of the League in the international legal literature projects the image of a League as being an experiment. ${ }^{22}$ It

16 See e.g. James Brierly, The Law of Nations (4th ed., 1949) p. 276; Georg Schwarzenberger, A Manual of International Law (3rd ed., 1952) p. 125; Charles de Visscher, Théories et Réalités en Droit International Public (4th ed., 1970) p. 69.

17 Rappard, supra note 14, p. 117; Schwarzenberger, supra note 16, p. 124; C. Wilfred Jenks, The Common Law of Mankind (1958) p. 62; de Visscher, supra note 16, p. 78; Roxburgh, supra note 14, vol. I, p. 280; Antony Anghie, "Colonialism and the Birth of International Instititutions: Sovereignty, Economy, and the Mandate System of the League of Nations", 34 NYU Journal of International Law and Politics (2002) p. 513, at 529-532; Robert Kolb, "The League of Nations in Retrospect", 22 Unif. Law Review (2017) pp. 145, 147. See also the idea of the Covenant of the League as a constitutional instrument emerged as early as 1930. See Arnold McNair, "The Functions and Differing Legal Character of Treaties", 11 British Yearbook of International Law (1925) pp. 110, 116-117.

18 Jenks, supra note 17, pp. 62-63.

19 See e.g. Schucking, supra note 14, p. 353; Jenks, supra note 17, p. 173; W. Rappard, supra note 14, p. 117, at 117; See Jenks, supra note 17, p. 173.

20 On these shifts in narratives and contradictions about the League, see David Kennedy, supra note 14, pp. 869-877.

21 See e.g. Benjamin Allen Coates, Legalist Empire: International Law and American Foreign Relations in the Early Twentieth Century (2016) pp. 162-167; Stephen Neff, Justice Among Nations: A History of International Law (2014) p. 351; Christian J. Tams, "World Courts as Guardians of Peace?", 15 Global Cooperation Research Papers (2016) p. 14S; Tuomas Lihr, "Elihu Root and International Legalism: Legalist Remarks on Collective Security and American Realism", Helsinki Law Review (2014) pp. 63-92. On the disappointment of Elihu Root, see Christian J. Tams, "World Courts as Guardians of Peace?" 15 Global Cooperation Research Papers (2016) p. 14. See also the literature cited by Kennedy, supra note 14, p. 869 .

22 See e.g. Schwarzenberger, supra note 16, p. 124; Arthur L. Goodhart, World Affairs (1947) p. 195; Jenks, supra note 17, p. 173; Georg Schwarzenberger, Power Politics: A Study of International Society (1951) pp. 291-307; Peter Hilpold, "The League of Nations and the 
is noteworthy that such "experiment narratives" about the League are usually accompanied by narratives of failure that depicts that experiment as unsuccessful ${ }^{23}$ as well as narratives that postulates a continuity between the League and the United Nations. ${ }^{24}$ The next section expands on these "experiment narratives" about the League and their concrete manifestations.

\section{Manifestations of the "Experiment Narrative" about the League of Nations}

As has been pointed out in the first section, "experiment narratives", as they are construed here, build on three intertwined elements: location in a formally defined past, narrativization of a failure or demise, and attribution of formative merit in the present. The following spells out these three constitutive elements as they manifest themselves in international legal discourses about the League.

\subsection{An Episode: A Formally Defined Past}

The belonging of the League to a well-delineated past and its representation as an institution with a formal beginning and end are rather common and do not warrant much discussion. The League of Nations birth is commonly associated with the Versailles conference leading to the adoption of the Covenant of the League. ${ }^{25}$ The demise of the League is captured through the outbreak of the Second World War, the minimal care-taking functions performed by the Secretary General at the time and the last session of the Assembly in April 1946

Protection of Minorities: Rediscovering a Great Experiment", 7 Max Planck Yearbook of United Nations Law (2013) p. 87; Rappard, supra note 14, p. 117; Guy Sinclair, To Reform the World: International Organizations and the Making of Modern States (2017) p. 21; Pablo de Azcárate, League of Nations and National Minorities:An Experiment (trans. Eileen E. Brooke, 1945); Cottrell, supra note 1; Carol Weisbrd, "Minorities and Diversities: The 'Remarkable Experiment' of the League of Nations" 8 Connecticut Journal of International Law (1992) p. 359; Michele D'Alessandro "Global Economic Governance and the Private Sector: The League of Nations' Experiment in the 1920s" in C. Dejung, N.P. Petersson (eds.), The Foundations of Worldwide Economic Integration: Power, Institutions, and Global Markets, 1850-1930 (2013) pp. 249-270.

23 See section 4.2.

24 See section $4 \cdot 3$.

25 See generally "Appendix: Covenant for the League of Nations Showing the Preliminary Reported Draft and the Covenant as Finally Adopted at the Plenary Session", 3 Proceedings of the Academy of Political Science in the City of New York (1919) pp. 127-154. 
leading to its liquidation, and its actual dissolution on 31 July $1947 .^{26}$ This formal delineation of the League in a formally defined past is very ordinary and uncontroversial.

\subsection{Causality: A Failure}

As was indicated above, narratives of failure constitute an important component of "experiment narratives" as, short of a failure, the practice or institution concerned would not have come to an end and would have fallen short of generating lessons for the present. Failure narratives about the League of Nations are commonplace. International lawyers in the 1920 and most of the 193os did not experience (and represent) the League as a failure. Failure narratives about the League rather date back to the late 1930s, that is when the collective security mechanism of the League underwent some severe stress and was bluntly flouted on a few occasions. ${ }^{27}$ Yet, it really is after the Second World War that failure narratives about the League became a general pattern. ${ }^{28}$ They remain common nowadays ${ }^{29}$ and are only rarely contested. ${ }^{30}$

Unsurprisingly, the object of the failure of the League is understood in many different ways in the legal literature. The most common understanding of a failure of the League pertains to collective security mechanism..$^{31}$ But this finding of a "failure" is also found in relation to the general economy of the Covenant

26 See League of Nations (1947) Final report presented to states members of the league of nations in accordance with the requirement of the final article of the resolution for the dissolution of the league of nations adopted by the assembly on April 18th, 1946, at its twenty-first ordinary session. Geneva: s.n (Series of League of Nations publications, general 1947, p. 1. See also the "Resolution for the Dissolution of the League of Nations, Adopted by the Assembly on April 18, 1946" 1 International Organization (1947) p. 246.

27 One witness claims on a failure as early as the 1936 Abyssinia crisis: See Charles G. Fenwick, "The 'Failure' of the League of Nations", 30 American Journal of International Law (1936) pp. 506-509. See also Charles A.W. Manning, "The 'Failure' of the League of Nations", 1 Agenda (1942) p. 1.

28 See e.g. Brierly, supra note 16, p. 276; Goodhart, supra note 22, p. 195.

29 See e.g. Christian Tams, "League of Nations" in R. Wolfrum (ed.) Max Planck Encyclopedia of Public International Law (2007) para. 4.

30 On the claim that the League exercised considerable power in shaping the world and especially peripheral regions and cannot be described as a failure in that sense, see Usha Natarajan, "Creating and Recreating Iraq: Legacies of the Mandate System in Contemporary Understandings of Third World Sovereignty", 24 Leiden Journal of International Law (2011) pp. 799-822.

31 See e.g. Fenwick, supra note 27, pp. 506-509; Brierly, supra note 16, p. 276; Paul Guggenheim, Traité de Droit international public, tome II (1954) pp. 264-268; Randall Lesaffer, "Too Much History: From War as Sanction to the Sanctioning of War", in Marc Weller (ed.), The Oxford Handbook of the Use of Force in International Law (2015) pp. 35, 51. 
of the League, ${ }^{32}$ the coordination with other international organizations, ${ }^{33}$ and its approach to the relation between politics and law. ${ }^{34}$

The reasons that are put forward to explain such a failure also vary a great deal ${ }^{35}$ and include explanations as diverse as the problem of nonmemberships of some main actors, ${ }^{36}$ the "return of power politics", ${ }^{37}$ the specific type of decision-making process provided by the Covenant and the architecture of the League, ${ }^{38}$ the configuration of the sanction mechanism, ${ }^{39}$ violence and nationalism, ${ }^{40}$ the kinship between the Peace Treaties and the League and the fact that the latter was a guardian of the former and thus of the 1919 settlement, ${ }^{41}$ the "absurd" consequences of the principles governing the League, ${ }^{42}$ the patchy character of the collective security system, ${ }^{43}$ the absence of a general prohibition of war, ${ }^{44}$ the anti-legalistic content of the Covenant, ${ }^{45}$ the Western-centricism ${ }^{46}$ or the European-centricism of the League, ${ }^{47}$ etc. The Abyssinia crisis is often held as a common crisis that pre-

32 Schwarzenberger, supra note 22, p. 291; C. de Visscher, supra note 16, pp. 70-71. Compare with the early discussion of the defects of the Covenant of the League, see Roxburgh, supra note 14 vol. 1, pp. 291-301.

33 Niels Blokker and Henry Schermers, International Institutional Law (6th ed., 2018) p. 1145, para. 1704 .

34 Tuomas Lihr, supra note 21, pp. 63-92.

35 For a comprehensive discussion of many possible reasons of the failure of the League, see de Visscher, supra note 16, pp. 69-78.

36 This is a very common reason invoked. See e.g. Randall Lesaffer, supra note 31 , pp. $5^{1-52}$; Sinclair, supra note 22, p. 21; Tams, supra note 29, para. 4.

37 See e.g. Schwarzenberger, supra note $22, \mathrm{p} .38$. See the remarks and the literature cited by Kennedy, supra note 14, pp. 871-877.

38 Tams, supra note 29, para. 30; Anne Peters, "Le Cheminement historique des organisations internationales: entre technocratie et démocratie", in P.M Dupuy and V. Chetail (eds.), The Roots of International Law : Liber Amicorum Peter Haggenmacher (2014) pp. 487, 500.

39 Schwarzenberger, supra note 22, p. 295.

40 Rappard, supra note 14, p. 174.

41 Schwarzenberger, supra note 16, p. 132; Tams, supra note 29, para. 4. On the Covenant and the peace treaties, see Kennedy, supra note 14, pp. 907-913; Rappard, supra note 14, pp. $178-181$.

42 Hans Morgenthau, "Political Limitations of the United Nations", in G.A. Lipsky (ed.), Law and Politics in the World Community (1953) p. 146.

43 Randall Lesaffer, supra note 31, p. 51.

44 Hersch Lauterpacht, Oppenheim's International Law, 7 th ed., (1952) tome II, p. 99 and 179183; see also Randall Lesaffer, supra note 31, pp. 51-54. On the failed attempt to incorporate Paris Pact in the League, see the remarks by Francis P. Walters, A History of the League of Nations: Volume I and Volume II (1952) vol. 2, p. 710.

45 Coates, supra note 21, pp. 162-167; Neff, supra note 21, p. 351.

46 Jenks, supra note 17, p. 63.

47 Sinclair, supra note 22, p. 76 . 
cipitated the demise of the League. ${ }^{48}$ The Second World War is seen as either cause or the consequence of the failure of the League. ${ }^{49}$ More recent claims about the perpetuation of colonization through the League mandate system, ${ }^{50}$ although pointing to the unprecedented impact of the League on shaping the Middle East,$^{51}$ are often accompanied by a failure narrative emphasizing the lack of emancipation of the peoples living in mandate territories. ${ }^{52}$

The foregoing should suffice to provide a snapshot of the great diversity of failure narratives about the League..$^{53}$ It is argued here that these failure narratives underpin the possibility of attributing formative merit to the League and are thus instrumental to the third component of "experiment narratives".

\subsection{Continuity with the Present: Attribution of Formative Value to the Past}

International lawyers confidently claim that the failure of the League was instructive and conducive to important lessons for subsequent international legal practice and institutions. ${ }^{54}$ The "lessons learnt" are numerous. The failure of the League is now commonly presented as having taught the architects of the post-Second World War regime a great deal, especially in terms of prohibiting aggression, ${ }^{55}$ organizing measures of coercion, ${ }^{56}$ the readiness to subject oneself to a supervisory body, ${ }^{57}$ making international organizations effective, ${ }^{58}$ enhancing the feeling of importance of international cooperation, ${ }^{59}$

48 See e.g. Fenwick, supra note 27, pp. 506-509; Brierly, supra note 16, p. 276; Schwarzenberger, supra note 16, p. 133. For an overview of the Italian crisis, see Guggenheim, supra note 31, pp. $264-268$.

49 See the remarks and the literature cited by Kennedy, supra note 14, p. 859.

50 On the mandate system, see generally Giovanni Distefano, "Article 22: Les Mandats", in R. Kolb (ed.), Commentaire sur le Pacte de la Société des Nations (2014), p. 841; Giovanni Distefano, "Les territoires sous mandat de la Société des Nations: colonialisme déguisé ou administration internationale", in P. Mahon and M.S. Nguyen (eds.), L'activité et l'espace - Droit du sport et aménagement du territoire. Mélanges en l'honneur de Piermarco Zen-Ruffinen (2011) p. 491.

$5^{1} \quad$ Usha Natarajan, supra note 30, p. 799.

$5^{2}$ Antony Anghie, supra note 17, p. 549. See also Sinclair, supra note 22, p. 22.

53 Kolb notes that the UN itself has not undergone the same severity of judgement as the League. See Kolb, supra note 17, p. 145.

54 See e.g. de Visscher, supra note 16, pp. 69 and 78.

55 Lauterpacht, supra note 43, p. 193.

56 Jenks, supra note 17, p. 193.

57 See Lauterpacht, supra note 43, pp. 97-98.

$5^{8}$ Jenks, supra note 17, p. 193.

59 de Visscher, supra note 16, p. 69. 
the non-generalization of the bindingness of decisions of international organizations, ${ }^{60}$ etc. The whole United Nations system is presented as the brainchild of the failure of the League of Nations. ${ }^{61}$ The numerous reforms ${ }^{62}$ of the Covenant of the League which were initiated - but not always completed $^{63}$ - are also said to have benefited the United Nations. ${ }^{64}$

It must be acknowledged that not all the "lessons learnt from the League" are ascribed to its failure. Some formative value is sometimes ascribed to those perceived successes and achievements of the League, for instance, in relation to the League activities in terms of disarmament, ${ }^{65}$ fight against slavery, ${ }^{66}$ the fight against terrorism, ${ }^{67}$ economic cooperation and financial cooperation, ${ }^{68}$

6o Blokker and Schermers, supra note 33, p. 856, para. 1319 .

61 Kolb, supra note 17, p. 145; Tams, supra note 29, para. 39; Schwarzenberger, supra note 22, pp. 458-485. Peters, supra note 38, p. 488; Blokker and Schermers, supra note 33, p. 177, para. 217. On this specific argument, see the remarks of Rose Parfitt, "Empire des Nègres Blancs: The Hybridity of International Personality and the Abyssinia Crisis 1935-1936", 24 Leiden Journal of International Law (2011) pp. 849, 85 o.

62 As early as 1921, the Second Assembly of the League of Nations passed a number of resolutions amending the Covenant of the League. See George Finch, "Amendments to the Covenant of the League of Nations", 16 American Journal of International Law (1922) pp. 263, 263; J. Paulus, "La Révision du Pacte de la Société des Nations", 3 o Revue générale de droit international public (1923) p. 525; Walters, supra note 44, vol. 2, p. 710; Lesaffer, supra note 31, p. 51. There were also 4 new amendments in 1925. See Manley Hudson, "Amendement of the Covenant of the League of Nations", 38 Harvard Law Review (1925) p. 903 .

63 On the establishment of a Reform Committee in 1936 by the League Assembly whose purpose was to adapt the principles of the League to the lessons of experience with a view to strengthening the authority of the League, see Schwarzenberger, supra note 22, p. 306. See also Manley Hudson, supra note 62, pp. 138-146 (Hudson emphasizes that in 19 years, very few amendments have been made; of 16 protocols of amendments, 14 opened to signature in 1921, 1924, and 1925, only 5 have been brought to force).

64 Walters, supra note 44, vol. 2, p. 713.

65 Lauterpacht, supra note 43, tome II, pp. 123-126.

66 See the International Slavery Convention adopted in 1926 under the auspices of the League of Nations. See Jenks, supra note 17, p. 233.

67 See 1937 Convention for the Prevention and Punishment of Terrorism adopted under the auspices of the League of Nations. See Ben Saul, "The Legal Response of the League of Nations to Terrorism", 4 Journal of International Criminal Justice (2006) p. 78.

68 See the remarks of Herren, supra note 13, p. 91; Rappard, supra note 14, pp. 187-199; Tams, supra note 29, para. 4 and para. 40. On the example of the 1937 International Sugar Agreement concluded under the auspices of the League, see Michael Fakhri, "The 1937 International Sugar Agreement: Neo-Colonial Cuba and Economic Aspects of the League of Nations", 24 Leiden Journal of International Law (2011) pp. 899-922. 
codification, ${ }^{69}$ registration of treaties,${ }^{70}$ protection of minorities, ${ }^{71}$ all the general activities of the League deemed "technical",72 and even collective security ${ }^{73}$ or the mandate system. ${ }^{74}$ Yet, it remains that most claims about the lessons learnt from the experience of the League are primarily a product of failure narratives about the League.

Interestingly and unsurprisingly, claims about the formative character of the failures of the League are supported by a presupposed continuity between the League and today's practices and institutions. In fact, as lessons have been learnt from the failure of the League according to the "experiment narratives" at work in the international legal literature, today's practices and institutions are supposed to continue the League. ${ }^{75}$ This continuity is particularly tangible in relation to the United Nations which is deemed to have continued the League and whose experience it benefited from. In fact, it is common to claim that the United Nations inherited the insights generated by the experiment of the League which it is, for this reason, continuing. ${ }^{76}$ Similar presuppositions of continuity are sometimes made with respect to international financial

69 On the meagre fruits of the codification efforts of the League of Nations, see Neff, supra note 21, pp. 362-364. See also Manley Hudson, "The Prospect for Future Codification", 26 American Journal of International Law (1932) p. 137.

70 For a discussion of the high number of treaties registered with the League, see Manley Hudson, "The Registration of Treaties", 24 Journal of International Law (1930) p. 752; Manley Hudson, "Legal Effect of Unregistered Treaties in Practice, Under Article 18 of the Covenant", 23 American Journal of International Law (1934) p. 546; See the Memorandum approved by the Council of the League of Nations (9 May 1920), 14 American Journal of International Law (1920) p. 366.

71 For a claim that the League's action in terms of protection of minorities has been successful, see Hilpold, supra note 22 p. 87; Rappard, supra note 14, pp. 181-187; Tams, supra note 29, para. 40; de Azcárate, supra note 22; Weisbrd, supra note 22, p. 359.

72 Anne Peters, supra note 38, p. 512.

73 Successes have been recognized in the area of collective security as the League seemingly prevented or diffused conflicts in Upper-Silesia (between Germany and Poland), Aland Islands (between Sweden and Finland), and the 'War of the Stray Dog' (between Greece and Bulgaria). Tams, supra note 29, para. 30 .

74 C. Tams, supra note 29, para. 40. See also the remarks of Jenks, supra note 17, p. 239.

75 See e.g. Jenks, supra note 17, pp. 192-193.

$7_{6}$ See generally Robert Kolb, supra note 17, pp. 145-147. Sinclair, supra note 22, pp. 113-159. The idea of continuity is also developed in several of the essays assembled in The League of Nations in Retrospect, Proceedings of a Symposium organized by the United Nations Library and the Graduate Institution of International Studies (1983). 
institutions ${ }^{77}$ and international administrative law. ${ }^{78}$ As a result, the League, now located in a clearly identified and limited past, having shown its flaws and limitations, can now generate insights for the present which it continues. With a clearly identified and limited past, an accompanying failure narrative, and the drawing of lessons for today's practice and institutions, "experiment narratives" about the League are fully in place.

The Costs and Virtues of "Experiment Narratives" in International Law

"Experiment narratives" like those witnessed in relation to the League and which have been described in the previous sections are certainly not unheard of in international legal literature. For instance, it is common to hear "experiment narratives" in relation to international dispute settlement, ${ }^{79}$ international trade law, ${ }^{80}$ international environmental law, ${ }^{81}$ human rights protection, ${ }^{82}$

77 Louis Pauly, "The League of Nations and the Foreshadowing of the International Monetary Fund", 201 Essays in International Finance (1996) 1.

78 Herren, supra note 13, p. 91.

79 See the contributions in Ignacio de la Rasilla and Jorge Vinuales (eds.), Experiments in International Adjudication. Historical Accounts (2019); Armand De Mestral, "Nafta Dispute Settlement Creative Experiment or Confusion?" in L. Bartels and F. Ortino (eds.), Regional Trade Agreements and the WTO Legal System (2006) p. 359; Eric J. Pan, "Assessing the NAFTA Chapter 19 Binational Panel System: An Experiment in International Adjudication." 40 Harvard International Law Journal (1999) p. 379; Todd Weiler et al. "International Investment Arbitration. Revolutionary Development or Doomed Experiment?", 10 Investment Treaty Arbitration and International Law (2017) p. 341; Paul Stein, "A Unique Experiment in Environment Dispute Resolution." 23 Environmental Policy and Law (1993) p. 277; Krishna Ahooja-Patel, The Greco-Bulgarian Dispute Before the League of Nations, 1925-1927: An Experiment in Peaceful Settlement (1974).

8o Hugh Corbet and David Robertson (eds.), Europe's Free Trade Area Experiment: EFTA and Economic Integration (1970); Sungjoon Cho, "Rethinking APEC: A New Experiment for a Post-Modern Institutional Arrangement”, in M. Matsushita and D. Ahn (eds.), WTO and East Asia: New Perspectives (2004) p. 381; Melaku Geboye Desta, "EC-ACP Economic Partnership Agreements and WTO Compatibility: An Experiment in North-South Interregional Agreements?" 43 Common Market Law Review (2006) 1343.

81 Meinhard Doelle, "The Paris Agreement: Historic Breakthrough or High Stakes Experiment?" 6 Climate Law: A Journal on Climate Change and the Law (2016) p. 1.

82 Clive R. Symmons, The Anglo-Irish Agreement and International Precedents: A Unique Experiment in Inter-State Co-Operation on Minority Rights (1987). 
international institutional law, ${ }^{83}$ territorial administration. ${ }^{84}$ It is submitted in this section that the success of "experiment narratives" in international legal discourses is not surprising. As a type of discourse, "experiment narratives" come with numerous discursive, cognitive, and imaginary benefits. Indeed, the resort to "experiment narratives" allows the constructions of necessities, causal links, and influences between past practices and institutions and present ones. ${ }^{85}$ They also perpetuate the feeling that international lawyers can know their past, learn from it, and control their future, which is very reassuring. There is no reason why international lawyers should forgo such comforting discourses, especially if they help uphold the authority and legitimacy of these global institutions they believe in.

In the specific context of the United Nations, held as the product of the lessons learnt from the League, "experiment narratives" carry important advantages too. For instance, "experiment narratives" help consolidate the current semi-constitutional status of the United Nations and the feeling of necessity associated with it. ${ }^{86}$ "Experiment narratives" about the League similarly facilitate the creation of a continuum between world events and the projection of an image of a global order in the present. ${ }^{87}$ More fundamentally, by virtue of the attribution of formative merit to past practices and institutions that accompany "experiment narratives", the latter simultaneously allow the construction of a progress narrative and the representation of the United Nations as the culmination of human progress. ${ }^{88}$ Indeed, "experiment narratives" about the League projects an image of world institutions and institutional

83 Bruno De Witte, "The European Union as an International Legal Experiment." In G. De Burca and J.H.H. Weiler (eds.), The Worlds of European Constitutionalism (2012) p. 19; Richard W. Pound, The World Anti-Doping Agency: An Experiment in International Law (2002); Henry L. Mason, The European Coal and Steel Community: Experiment in Supranationalism (1955); N. Piers Ludlow, "The European Commission and the Rise of Coreper: A Controlled Experiment." In W. Kaiser, B. Leucht and M. Rasmussen (eds.) The History of the European Union: Origins of a Trans- and Supranational Polity, 1950-72 (2009) pp. $189-205$.

84 Georges Kaeckenbeeck, The International Experiment of Upper Silesia: A Study in the Working of the Upper Silesian Settlement, 1922-1937 (1942).

85 See generally White, supra note 7 , p. 275 (History-writing: naming, grouping, relating through causation that explain changes); Barthes, supra note 8, p. 72; Carr, supra note 10, p. 40; Keith Jenkins, supra note 7, p. 61.

86 See generally Régis Chemain and Alain Pellet (eds.), La Charte des Nations Unies, Constitution Mondiale? (2006).

87 See also Wolfgang Preiser, "History of International Law, Basic Questions and Principles" in R. Wolfrum (ed.) Max Planck Encyclopedia of Public International Law (2007) para. 15.

88 See the critical remarks on the general progress narrative about international organizations see B.S. Chimni, supra note 12. See also Inis L. Claude, Swords into Ploughshares: The 
practices as constantly refined and improved through the accumulation of knowledge including the knowledge accumulated about the League. ${ }^{89}$ At the same time, "experiment narratives" helps play down the catastrophes and human disasters possibly associated with the League by over-emphasizing the formative character of the events concerned, thereby shedding a positive light thereon. Such progressive representation enables present actors to better fend off any possible hostility against the practice or institution concerned, ${ }^{90}$ while reinforcing the feeling that the League belongs to their past and that they are the proud heirs thereof.91

It is submitted here that "experiment narratives" also have a cost. They obviously repress the imagination of international lawyers and bar the possibility of alternative histories, and of all sorts of narratives that can be created and supported by inventing a new past. ${ }^{92}$ In doing so, they confine international lawyers to certain histories of international law and international institutions, and especially ones with Western-centric geography. In confining international lawyers to certain Western-centric histories, "experiment narratives" bear a legitimizing effect about such geography. ${ }^{93}$ In the same vein, "experiment narratives" about the League thwarts international lawyers' ability to take a hard look at the League and its legacy by fear of de-legitimizing the brainchild of that formative experience, namely the United Nations.

It is argued, at this ultimate stage of this article, that there is yet another peril lying in "experiment narratives" vindication of the present as a brainchild of the lessons learnt from a failed past. This peril originates in international lawyers' confinement to the "knowledge" of the past and of the lessons therefrom that comes with "experiment narratives". Indeed, knowing one's past and the lessons learnt from it, significantly reduces international lawyers' ability to respond to their past or the lessons therefrom being used against them and the institutions they value. At times where international discourses seem to have lost much decency, international lawyers cannot exclude that their "experiment narratives" are recuperated by post-truth delinquents to repudiate all what they have tried to preserve by virtue of such narratives. After all,

Problems and Progress of International Organization (4th ed., 1971). See also the remarks of Rose Parfitt, supra note 61, p. 850.

89 Kennedy, supra note 14, pp. 841-842.

$90 \quad$ Michel Foucault, L'archéologie du savoir (1969) p. 25.

91 Ibid., pp. 22-23.

92 White, supra note 7, pp. 126-127. See also Theodor W. Adorno, Negative Dialectics (trans. by E.B. Ashton, 1973) pp. 3-13 and 50.

93 See generally Sundhya Pahuja, "Laws of Encounter: A Jurisdictional Account of International Law" 1 London Review of International Law (2013) p. 63. 
"experiment narratives" offer no more security than any other "scientific" discourses. ${ }^{94}$ This is why, although benefiting from the comfort of "experiment narratives", international lawyers should always stand ready to reinvent their past in order to defend what they believe in. That means ensuring that they do not find themselves cornered in the cell of their own narratives. If the attacks against what they value so require, they should be ready to dismantle their "experiment narratives" and start the historical experiment all over again. ${ }^{95}$

94 Roland Barthes, L'aventure sémiologique (1985) p. 13.

95 On the idea of history as narrative (récit), see generally Jacques Rancière, Les mots de l'histoire. Essai de poétique du savoir (1992). 